\title{
Transitions in adolescent boys and young Men's high-risk sexual behaviour in India
}

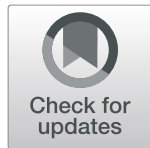

Santosh Kumar Sharma ${ }^{1 *}$ (D) and Deepanjali Vishwakarma²

\begin{abstract}
Background: The sexual behaviour of adolescents is of importance due to the engagement in risky sexual activity at a too early age, which may be associated with the adverse outcomes. The study aims to understand the transitions in adolescent boys and young men's high-risk sexual behaviour in India using two rounds of Indian demographic health survey, NFHS-3 (2005-06) and NFHS-4 (2015-16).

Methods: A total of 25,538 in NFHS-3 (2005-06) and 35,112 in NFHS-4 (2015-16) men were considered for the analysis. Men have been divided into two age groups as 15-19years (adolescent) and 20-24 (young men) for comparison purposes. Descriptive and multivariate statistics have been used.
\end{abstract}

Results: Overall, high-risk sexual behaviour has increased among adolescent boys (64 to 70\%) and young men (18 to 27\%) from 2005-06 to 2015-16. The trend of live-in relationship has increased among adolescent boys of rural areas (0.6 to 6.0\%) as well as in urban areas (3.1 to 10.9\%) over the last 10 years. Adolescent boys having 10th and above years of schooling ( $A O R=1.98 ; p<0.01$ ), residing in urban areas ( $A O R=2.23 ; p<0.01$ ), and belonging to the affluent class of households ( $A O R=1.41 ; p<0.05$ ) were more likely to engage in high-risk sexual activity than the young men in India. The odds of high-risk sexual behaviour was higher among alcohol-using adolescent boys $(\mathrm{AOR}=1.82 ; p<0.01)$ and young men $(\mathrm{AOR}=2.38 ; p<0.01)$ in $2015-16$.

Conclusions: The study concludes that early sexual debut, lower prevalence of condom use at first sexual experience, tendency of live-in-relationship, and alcohol consumption indicate the hazardous interconnection between such behaviours among adolescent boys over the last decade which placed them at higher-risky sexual behaviour as compared to young men. Adolescent' sexual behaviours have both short-term and long-term consequences, and interventions that focus on multiple domains of risk may be the most effective in helping to promote broad reproductive health among young adults.

Keywords: Adolescents, High-risk sexual behaviour, Multiple sexual partner, Relationship, Condom use, Alcohol

\section{Background}

Adolescent in India comprises almost $22 \%$ of India's population, and their number is only going to increase in the future $[1,2]$. They are growing up in an environment that is very different from their parents in which they grew up. The sexual conduct of adolescents is of significance because of the expanding number of

\footnotetext{
* Correspondence: santoshiips88@gmail.com

1 International Institute for Population Sciences, Deonar, Govandi Station Road, Mumbai, Maharashtra 400088, India

Full list of author information is available at the end of the article
}

sexually active adolescents comprehensively [3, 4]. While the commencement of sexual action is a piece of typical conduct and advancement, it might likewise be related with antagonistic results, particularly when sexual conduct includes commitment in sexual activity at a too early age, or regardless of the risk involved [5]. Adolescence is a period of transition when an individual's personality develops which includes his/her masculinity/ femininity social, cultural, economic and biological events take place, which set the stage for adulthood [2].

C C The Author(s). 2020 Open Access This article is licensed under a Creative Commons Attribution 4.0 International License, which permits use, sharing, adaptation, distribution and reproduction in any medium or format, as long as you give appropriate credit to the original author(s) and the source, provide a link to the Creative Commons licence, and indicate if changes were made. The images or other third party material in this article are included in the article's Creative Commons licence, unless indicated otherwise in a credit line to the material. If material is not included in the article's Creative Commons licence and your intended use is not permitted by statutory regulation or exceeds the permitted use, you will need to obtain permission directly from the copyright holder. To view a copy of this licence, visit http://creativecommons.org/licenses/by/4.0/ The Creative Commons Public Domain Dedication waiver (http://creativecommons.org/publicdomain/zero/1.0/) applies to the data made available in this article, unless otherwise stated in a credit line to the data. 
The traditional Indian society has been allied with illustration of sexuality and sexual liberalism in the form of art. The first text to contemplate sexual expression as a science was Kamasutra, which originated before the sixth century [6]. Regardless of even the old content of Indian religious philosophy perceiving the principal idea of puberty and pushing unambiguous implicit rules for the stage, the conception of adolescence is moderately new in current India, and the adolescent has open space in strategy plans or policy formulations.

In modern India, age limits of adolescents varies from program to program or policy to achieve their goals. According to the National Youth Policy of India, adolescents is defined as the age group 13-19 years; while, the Reproductive and Child Health program makes reference to adolescents as being between 10 and 19 years old. The Juvenile Justice (Care and Protection) Act (JJ Act) 2000 and now the JJ Act 2015, and the Protection of Children from Sexual Offenses Act (POCSO Act), 2012 characterize all people up to the age of 18 years as adolescents [7].

There are many factors which encompasses by adolescent's sexuality such as developing intimate partner relationships, gender identity, sexual orientation, religion and culture [8]. Sexual behaviour perhaps influenced by many factors like physiological cultural and social pressures, which vary from generation to generation [3]. Sexual exposure during adolescence is a matter of grave concern due to the risk of transmission of sexually transmitted infections, including HIV infection/AIDS, teenage pregnancy, and adolescent fatherhood $[9,10]$. Early sexual introduction prompting HIV infection involves extraordinary concern in many developing, as well as underdeveloped countries [11]. Joshi and Chauhan [12] stated that there is a high level of premarital and unsafe sexual behaviour among young individuals in India. A study conducted by Sharma [13] on adolescents and youth in low income slums of Mumbai articulated that the phase of adolescence is also marked by the experimentation and influence of friends and peer groups. During this adolescent's age, they begin investing more time exterior the home, getting away the guardian ship of the adult members of their families. Adolescents and young individuals often get fascinated by mass media, friends, and peer pressure without sufficient knowledge of prevention, which inspires them to indulge in hazardous ways of life such as smoking, alcohol or drug use, and sexual activity. As a consequence, the hazard of sexually transmitted diseases (STDs) and HIV/AIDS may be noteworthy among adolescents and young individuals [14]. Numerous studies from other countries evident that there are number of factors such as multiple partner, relationships, and family factors, associated with condom use among young individuals [15-17]. At the individual level, condom use among youth is positively correlated with several factors such as schooling, self-worth, awareness about the advantageous of condom use, anticipated infection risk, and socio-economic status of households, whereas there is negative association between sexual debut at early age and substance use [17-19].

In view of the above, the study was undertaken to understand the transitions in adolescent boys and young men's high-risk sexual behaviour in India using the preceding two rounds of Indian demographic health survey, NFHS-3 (2005-06) and NFHS-4 (2015-16). The specific objectives of the study are to understand the changes in risky sexual behaviour and safe sexual practices at first and last sexual experience among adolescent boys and young men in India over the last decade, and to determine the factors associated with risky sexual behaviour among adolescent boys (15-19) and young men (20-24) in India.

\section{Methods}

The analysis of this study is based on two rounds of National Family Health Survey (NFHS) survey, an Indian variant of Demographic and Health Surveys (DHS), conducted during 2005-06 and 2015-2016 which is accessible on the Demographic and Health Survey (DHS) website https:// dhsprogram.com/information/dataset/India_Standard-

DHS_2015.cfm?flag=1 therefore, doesn't require any ethical approval for the use of data.The National Family Health Surveys (NFHS) are part of the global Demographic and Health Surveys (DHS), conducted by the IIPS (Mumbai), with support from the Ministry of Health and Family Welfare (MoHFW), Government of India and ICF International Inc. [20]. NFHS is a nationally representative, large scale, repeated cross sectional survey in representative samples of households throughout India. NFHS provides important aspects of maternal, child, adolescent and adult health indicators. Details about the NFHS-3 and NFHS-4 sampling designs, tools, and protocols presented in the national reports of NFHS [20] and all relevant information is available in the public domain on http://rchiips.org/NFHS.shtml.

The NFHS survey collected information from a nationally representative sample of 74,369 in NFHS-3 (2005-06) and 112,122 men aged 15-54 years during the period NFHS-4 (2015-16). For the present study, only men aged 15-24 years have been considered. Therefore, a total of 25,538 men in NFHS-3 and 35,712 men aged 15-24 years in NFHS-4 were considered for the analysis. In this study, men have been divided into two age groups as $15-19$ years (adolescent boys) and 20-24 years (young men) for comparison purpose.

\section{Outcome variables}

The study used 'ever had sexual intercourse', 'age at first sex', 'condom use at first sex', 'multiple sexual partners in the past 12 months (having more than one partners)', 
'relationship with most recent sexual partners', 'condom used with most recent sexual partners' and 'high-risk sexual behaviour in the past 12months' as dependent variables. National Family Health Surveys has defined high-risk sexual behaviour as sexual intercourse, in the last 12 months, with someone who is neither a spouse nor a cohabiting partner [20].

\section{Independent variables}

A set of independent variables such as socio-economic characteristics, demographic characteristics and geographical regions of the respondents were included in the analysis. The explanatory variables included in this study are years of schooling, place of residence (rural, urban), regular exposure of media (no, yes), household wealth index (poorest, poorer, middle, richer, richest), religion (Hindu, Muslims and others), membership to social group (Scheduled Castes - SC, Scheduled Tribes - ST, Others), region of residence (Southern, Northern, North-eastern, Central, Eastern and Western), comprehensive knowledge about HIV/AIDS (no, yes), and alcohol use (no, yes).

\section{Statistical analysis}

Bivariate and multivariate analysis was applied to understand the changes in adolescent boys and young men's sexual behaviour during the last decade according to their socio-economic, demographic characteristics and region of residence. A Binary logistic regression was performed to identify the determinants of risky sexual behaviour among adolescent boys and young men.

Binary logistic regression analysis is useful when the outcome variable has only two categories ( 0 and 1$)$. The basic form of logistic regression model, which yields the probability of occurring of an event, depicted as:

$$
p=\frac{1}{1+e-z}=\frac{e^{z}}{1+e^{z}}
$$

While analysing the association between multi-partner sexual behaviour and selected background characteristics, it was observed that the multi-partner sexual behaviour variable was excess with zero outcome. To overcome this problem we have used a zero inflated Poisson regression model to determine the incidence rate ratio (IRR) of having multiple sexual partners. The zero-inflated Poisson (ZIP) regression model is a modification of the familiar Poisson regression model that allows for an over-abundance of zero counts in the data. The distribution of multi-partner sexual behaviour variable combines the Poisson distribution and the logit distribution. For each observation in the multi-partner sexual behaviour, there are two possible regimes. In one regime the outcome is always a zero count, while in other regime the counts (including zeros) follow a standard Poisson process. Suppose that outcome one occurs with probability $\pi$ and outcome two occurs with probability $1-\pi$. Therefore, the probability distribution of the ZIP random variable $y_{i}$ (multi-partner sexual behaviour) can be written as

$$
\begin{array}{ll}
\operatorname{Pr}\left(y_{i}=j\right)=\pi_{i}+\left(1-\pi_{\mathrm{i}}\right) \exp \left(-\ddot{E}_{i}\right) & \text { if } \mathbf{j}=0 \\
\operatorname{Pr}\left(y_{i}=j\right)=\left(1-\pi_{i}\right) \dot{E}^{j i} \exp \left(-\ddot{E}_{i}\right) / \mathrm{y}_{i} ! & \text { if } \mathbf{j}>0
\end{array}
$$

Where the outcome variable $y_{i}$ has any non-negative integer value, $\mu$ is the expected Poisson count for the $\mathrm{i}^{\text {th }}$ individual, and $\pi_{\mathrm{i}}$ is the logistic link function.

In the ZIP regression model, the predictors affecting $\pi_{i}$ and $\mu_{\mathrm{i}}$ may or may not be the same. If the same covariates affect $\pi_{i}$ and $\mu_{i}$, we can write $\pi_{i}$ as a function of $\mu_{i}$ to obtain.

$$
\begin{aligned}
\log (\mu i) & =\sum_{j=1}^{k}(\mathrm{x} i j \beta j) \text { and } \operatorname{logit}\left(\pi_{i}\right) \log \left(\left(\frac{\pi i}{1-\pi i}\right) .\right. \\
& =-\tau \sum_{j=1}^{k}(\mathrm{xij} \beta j)
\end{aligned}
$$

Where $\beta j(j=123 \ldots \mathrm{k})$ is the regression coefficients unknown parameters that are estimated from a set of data.

Statistical analysis was carried out using STATA 13.0 version software. All the analyses were weighted using NFFHS-4 provided sampling weights to account for survey design.

\section{Results}

Table 1 shows the prevalence of ever had sexual intercourse among young men (15-24 years) during 2005-06 and 2015-16. Total 6881 in 2005-06 and 7851 adolescent boys and young men in 2015-16 ever had sexual intercourse. Figure 1 shows that ever had sexual intercourse has substantially decreased among adolescent boys (11 to $8 \%$ ) and young men (44 to $38 \%$ ) during the last decade. Ever had sexual intercourse has decreased among uneducated young men from $48 \%$ to $36 \%$ during NFHS-3 to NFHS-4; however, it has slightly increased among higher educated men during the last decade. Although, ever had sexual intercourse is higher among young men residing in urban areas than the rural areas in both the consecutive survey, the prevalence of ever had sexual intercourse decreased from 32\% in 2005-06 to $25 \%$ in $2015-16$ among young men residing in urban areas (Fig. 3). Around three-fifths of young men belonging to SC/ST had ever been sexually active during 2005-

Table 1 Prevalence of ever had sex among youth (15-24) during NFHS-3 and NFHS-4

\begin{tabular}{lll}
\hline & NFHS-3 (2005-06) & NFHS-4 (2015-16) \\
\hline No. of Women & 6881 & 7851 \\
$\%$ & 26.9 & 22.4 \\
\hline
\end{tabular}




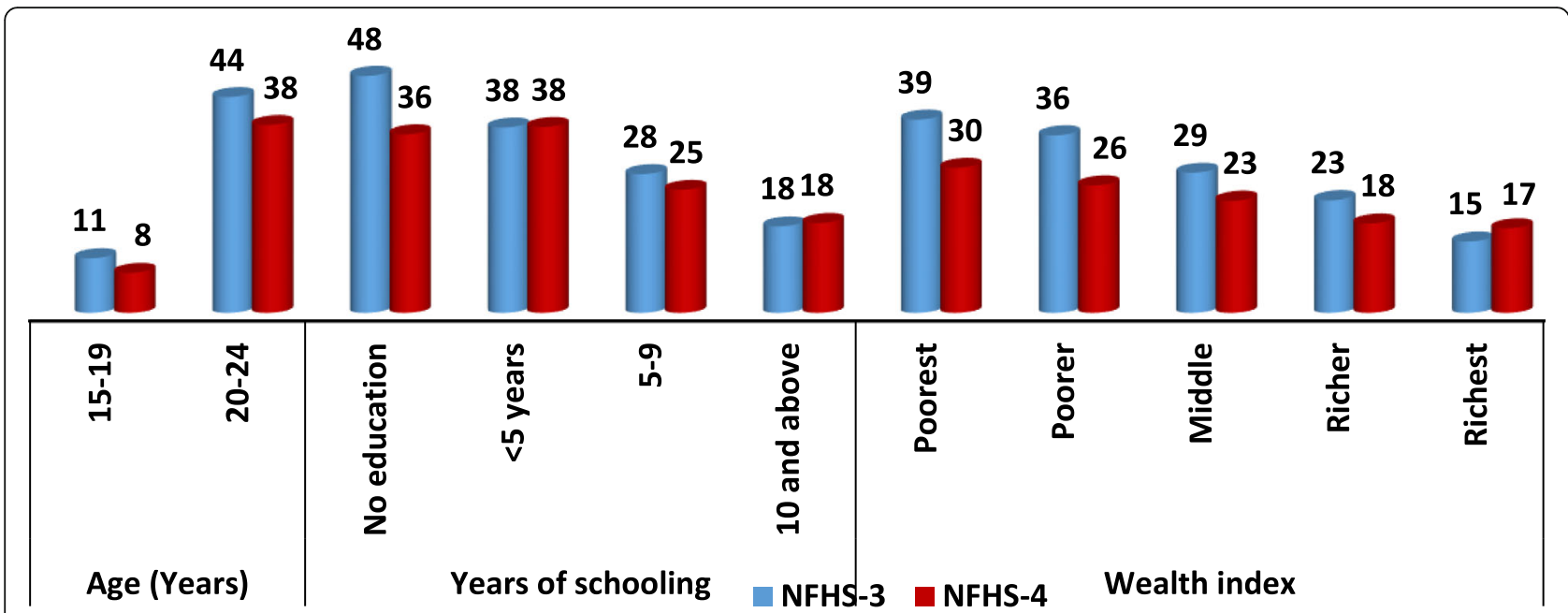

Fig. 1 Prevalence of ever had sex among youth (15-24) according to age, education and wealth quintile

06, whereas this proportion decreased in 2015-16 (Fig. 2). In case of socioeconomic status, as wealth index increases ever had sexual activity among adolescent boys and young men decreased in both the consecutive surveys (Fig. 1). A Central region of India shows the highest proportions of adolescent boys and young men involved in sexual activity in both the consecutive surveys than the other geographic regions; however, the percentage has substantially declined in all the geographic areas in India during the last decade (Fig. 3).

Table 2 shows the transition of mean age at first sex and condom use at first sex among adolescent boys (1519 years) and young men (20-24 years) in India over the last decade. Results show that the initiation of sexual activity is still early among adolescent boys (16 years) and young men (19 years) over the last decade. Condom use at first sex among adolescent boys (19 to 34\%) and young men (14 to $26 \%$ ) have considerably increased almost double from 2005 to 06 to 2015-16 respectively.
Findings evident that condom use at first sex is higher among adolescent boys and young men residing in an urban setting, belonging to the other backward castes $(\mathrm{OBC})$, and who have regular exposure to media than their counterparts in both the survey.

Adolescent boys and young men belonging to betteroff households are more likely to use a condom at first sex in both the survey. Condom used at first sex has increased among adolescent boys (21 to $40 \%$ ) and young men (16 to $32 \%$ ), even those who consumed alcohol during the last decade. Condom use at first sex among adolescent boys has rapidly increased during last 10 years in the Eastern and Southern region, although other geographic region also showed the increased prevalence of condom use at first sex from NFHS-3 to NFHS-4.

\section{Multi-partner sexual behaviour}

Table 3 shows the percentage distribution of adolescent boys and young men having multiple sexual partners in

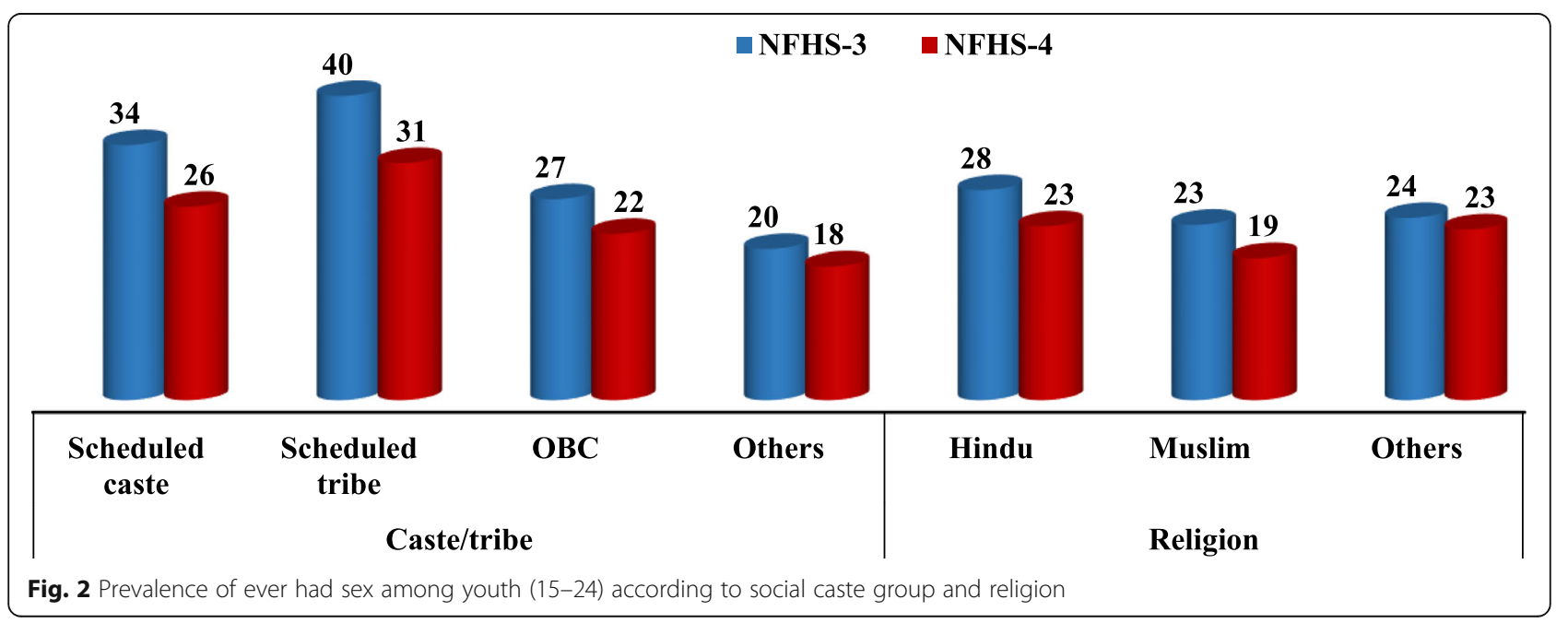




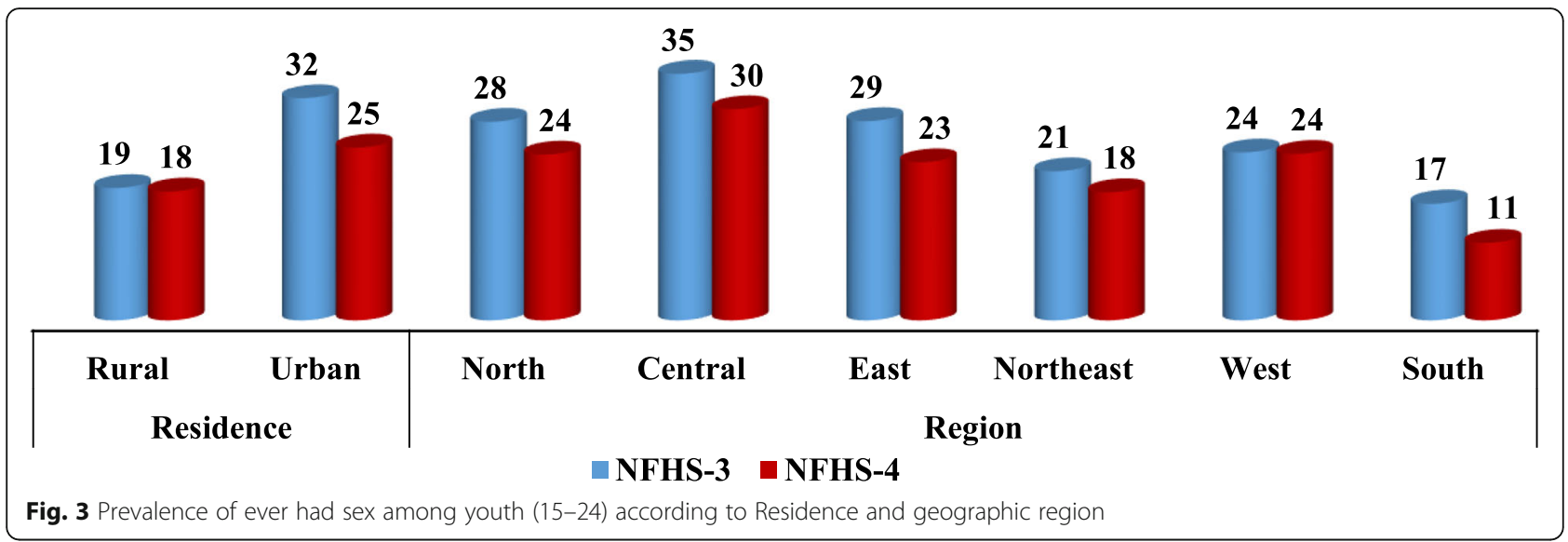

the last 12 months and the results of zero-inflated poison regression of having multiple sexual partners in 2005-06 and 2015-16 in India. It is evident that multi-partner sexual behaviour among adolescent boys decreased (15 to $10 \%)$ during the last 10 years. The prevalence of multiple sexual partner has declined during the last 10 years among adolescents boys having 10th and above year of schooling (17.2 to $8.6 \%$ ). In 2015-16, adolescent boys residing in rural setting (7\%) are having more multiple sexual partners than the urban setting (11\%). An estimated $7 \%$ of adolescent boys belonging to other religion (Christian, Sikhs, Buddhism, Jain, etc.) reported multiple sexual partners in 2015-16 while in 2005-06, this proportion was almost four times higher.

The multi-partner sexual behaviour has also decreased among adolescent boys who have regular exposure of mass media 2005-06 (15\%) to 2015-16 (10\%). A rapid declining pattern was observed in the multiple sexual partner behaviour among adolescent boys belonging to the affluent class of households from $29 \%$ in $2005-06$ to $7 \%$ in 2015-16. Adolescent boys who have comprehensive knowledge of HIV/AIDS were more likely (IRR $=1.67 ; p<0.01$ ) to have more than one partner in 2005-06 whereas in 2015-16, they are less likely to report multiple sexual partners. Alcohol-using adolescent boys and young men are more likely to have more than one partner in both the survey, the rate of decrement is also observed over the last one decade.

Regional differences were also observed among adolescent boys and young men. In 2015-16, Central (12\%), Eastern (11\%) and Western (10.0\%) region of adolescent boys shows the higher multi-partner sexual behaviour, whereas in NFHS-3, Northern (18\%), Eastern (16\%) and Western (24\%) region of adolescent boys shows higher multi-partner behaviour than the other geographic regions of India. Zero-inflated Poisson regression results also revealed that adolescent boys belonging to Central $(\mathrm{IRR}=1.77 ; p<0.01)$, and Western region (IRR $=1.56$; $\mathrm{p}<0.01$ ) were more likely to have more than one partner in 2015-16 than the other counterparts.
Relationship status with the most recent sexual partners Table 4 portrays the status of relationship with the most recent partner among adolescent boys and young men according to their place of residence in 2005-06 and 2015-16 in India. Results show that relationship status with girlfriends/fiancé (57\%), commercial sex workers (8.4\%), and live-in partner (11\%) is higher among adolescent boys residing in urban areas than the young men living in urban areas during 2015-16. It was observed that the percentage has increased in rural areas among adolescent boys having girlfriends/fiancé (29.6 to 48.6\%), casual acquaintance (2.3 to $10.6 \%$ ), commercial sex workers (2.3 to $5.5 \%)$ and live-in partner (0.6 to $6 \%$ ) during the last one decade.

Relationships status with most recent sexual partners has also been analysed with the socioeconomic status of the adolescent boys and young men in both the survey (Table 5). Adolescent boys belonging to the poorest quintile (41\%) are more likely to have girlfriends/fiancé in 2015-16 than the adolescent boys in 2005-06. However, the culture of girlfriends/fiancé among adolescent boys have considerably increased in across the wealth quintile from 2005 to 06 to 2015-16. During the last 10 years, live-in partner relationships have also increased among adolescent boys, whether they belong to lower socio-economic status of households (0.0 to 6.3\%) or higher socioeconomic status (1.4 to $13 \%$ ) from NFHS-3 to NFHS-4.

\section{Condom use during last sexual intercourse}

Overall, condom use during last sexual intercourse among adolescent boys (23 to 69\%) and young men (13 to $65 \%$ ) has rapidly increased over the last one decade (Table 6). It was observed that as the level of education increases, condom use during last sexual intercourse also increased among adolescent boys and young men in both the survey. The prevalence of condom use during last sexual intercourse increased among adolescent boys (37 to $72 \%$ ) and young men (20 to 67\%) from NFHS-3 
Table 2 Mean age at first sex and condom use at first sex among adolescent boys and young men in India

\begin{tabular}{|c|c|c|c|c|c|c|c|c|}
\hline \multirow[b]{3}{*}{$\begin{array}{l}\text { Background } \\
\text { Characteristic }\end{array}$} & \multicolumn{4}{|l|}{ NFHS-3 (2005-06) } & \multicolumn{4}{|c|}{ NFHS-4 (2015-16) } \\
\hline & \multicolumn{2}{|l|}{$15-19$} & \multicolumn{2}{|l|}{$20-24$} & \multicolumn{2}{|l|}{$15-19$} & \multicolumn{2}{|l|}{$20-24$} \\
\hline & $\begin{array}{l}\text { Mean age at } \\
\text { first sex(years) }\end{array}$ & $\begin{array}{l}\text { Condom use } \\
\text { at first sex } \\
(\%)\end{array}$ & $\begin{array}{l}\text { Mean age at } \\
\text { first sex } \\
\text { (years) }\end{array}$ & $\begin{array}{l}\text { Condom use } \\
\text { at first sex } \\
\text { (\%) }\end{array}$ & $\begin{array}{l}\text { Mean age at } \\
\text { first sex } \\
\text { (years) }\end{array}$ & $\begin{array}{l}\text { Condom use } \\
\text { at first sex } \\
\text { (\%) }\end{array}$ & $\begin{array}{l}\text { Mean age at } \\
\text { first sex } \\
\text { (years) }\end{array}$ & $\begin{array}{l}\text { Condom use } \\
\text { at first sex } \\
\text { (\%) }\end{array}$ \\
\hline \multicolumn{9}{|l|}{ Years of schooling } \\
\hline No education & 15.7 & 11.7 & 18.6 & 5.4 & 16.2 & 30.8 & 19.1 & 16.2 \\
\hline$<5$ & 15.9 & 9.9 & 19.1 & 9.5 & 16.1 & 34.0 & 19.1 & 15.2 \\
\hline $5-9$ & 15.7 & 19.5 & 19.0 & 13.8 & 15.9 & 30.4 & 19.3 & 20.2 \\
\hline 10 and above & 16.1 & 24.1 & 19.4 & 23.1 & 16.6 & 38.1 & 19.7 & 34.6 \\
\hline \multicolumn{9}{|l|}{ Place of residence } \\
\hline Rural & 15.6 & 13.8 & 18.8 & 10.5 & 16.2 & 30.5 & 19.4 & 21.0 \\
\hline Urban & 16.1 & 34.0 & 19.4 & 23.5 & 16.5 & 43.6 & 19.6 & 37.5 \\
\hline \multicolumn{9}{|l|}{ Religion } \\
\hline Hindu & 15.7 & 16.6 & 19.1 & 13.4 & 16.2 & 31.4 & 19.4 & 26.6 \\
\hline Muslim & 15.8 & 25.2 & 19.2 & 15.3 & 16.3 & 46.9 & 19.5 & 21.6 \\
\hline Others & 16.3 & 34.1 & 18.8 & 23.2 & 16.6 & 45.1 & 19.5 & 30.2 \\
\hline \multicolumn{9}{|l|}{ Caste/tribe } \\
\hline $\begin{array}{l}\text { Scheduled } \\
\text { caste }\end{array}$ & 15.6 & 13.9 & 19.0 & 14.6 & 16.5 & 36.0 & 19.5 & 25.8 \\
\hline Scheduled tribe & 16.1 & 13.7 & 18.6 & 7.0 & 16.2 & 25.5 & 19.1 & 16.0 \\
\hline $\begin{array}{l}\text { Other } \\
\text { backward class }\end{array}$ & 15.8 & 14.9 & 19.0 & 11.1 & 16.1 & 30.8 & 19.4 & 25.9 \\
\hline Others & 15.9 & 31.6 & 19.5 & 22.3 & 16.5 & 45.8 & 19.8 & 32.3 \\
\hline \multicolumn{9}{|c|}{ Regular exposure of media } \\
\hline No & 15.9 & 12.3 & 18.7 & 5.0 & 16.2 & 17.9 & 19.2 & 14.5 \\
\hline Yes & 15.8 & 19.8 & 19.1 & 16.4 & 16.3 & 37.8 & 19.5 & 28.8 \\
\hline \multicolumn{9}{|l|}{ Wealth index } \\
\hline Poorest & 15.4 & 11.7 & 18.3 & 5.5 & 16.0 & 21.6 & 19.1 & 15.6 \\
\hline Poorer & 15.6 & 12.2 & 18.8 & 8.8 & 16.2 & 29.8 & 19.3 & 20.0 \\
\hline Middle & 15.8 & 14.1 & 19.0 & 13.8 & 16.2 & 30.0 & 19.5 & 25.4 \\
\hline Richer & 15.9 & 26.7 & 19.3 & 18.7 & 16.5 & 44.1 & 19.7 & 30.9 \\
\hline Richest & 16.3 & 41.6 & 19.7 & 30.7 & 16.7 & 56.0 & 19.9 & 42.6 \\
\hline \multicolumn{9}{|c|}{ Comprehensive knowledge about HIV/AIDS } \\
\hline No & 15.7 & 18.9 & 19.0 & 14.1 & 16.2 & 30.3 & 19.5 & 25.3 \\
\hline Yes & 16.0 & 25.8 & 19.3 & 19.9 & 16.6 & 40.9 & 19.6 & 33.4 \\
\hline \multicolumn{9}{|l|}{ Alcohol Use } \\
\hline No & 15.7 & 17.1 & 19.2 & 13.0 & 17.1 & 31.9 & 13.0 & 23.8 \\
\hline Yes & 16.0 & 21.4 & 18.9 & 15.9 & 21.4 & 39.8 & 15.9 & 31.6 \\
\hline \multicolumn{9}{|l|}{ Region } \\
\hline North & 15.9 & 29.2 & 18.9 & 1.6 & 16.6 & 36.0 & 19.6 & 28.6 \\
\hline Central & 15.4 & 15.8 & 18.5 & 10.7 & 16.0 & 30.4 & 19.2 & 24.1 \\
\hline East & 16.1 & 10.2 & 19.2 & 14.1 & 16.2 & 34.0 & 19.6 & 21.2 \\
\hline Northeast & 16.2 & 21.0 & 18.9 & 11.6 & 16.4 & 16.2 & 19.4 & 15.2 \\
\hline West & 15.7 & 31.5 & 19.8 & 23.6 & 16.4 & 38.8 & 19.4 & 37.3 \\
\hline South & 16.4 & 18.5 & 19.7 & 12.0 & 16.7 & 46.5 & 20.5 & 19.1 \\
\hline Total & 15.8 & 18.5 & 19.1 & 14.1 & 16.3 & 34.2 & 19.5 & 26.1 \\
\hline
\end{tabular}


to NFHS-4 those who have comprehensive knowledge of HIV/AIDS.

The results also reported that the prevalence of condom use during last sexual intercourse increased among alcohol-using adolescent boys and young men over the last one decade. Regional differences was also observed in the prevalence of condom use during last sexual intercourse in the last decade, as Southern region of adolescent boys and young men reporting higher prevalence than the other geographic regions of India in 2015-16. Condom use during last sexual intercourse in Central (20\% \& 12 to $66 \%$ \& $58 \%$ ), Eastern (14\% \& 7 to $66 \%$ \& $65 \%$ ) have rapidly increased among adolescent boys and young men from 2005 to 06 to $2015-16$ respectively.

\section{High-risk sexual behaviour in the past 12 months}

Table 7 estimated the high-risk sexual behaviour in the past 12 months among adolescent boys and young men in India. Overall, high-risk sexual behaviour has increased among adolescent boys (64 to $70 \%$ ) and young men (18 to $27 \%$ ) from 2005 to 06 to $2015-16$. The odds of engaging in high-risk sexual behaviour in the past 12 months was higher among adolescent boys $(\mathrm{AOR}=1.98$; $p<0.01$ ), and young men (AOR $=2.74 ; p<0.01$ ), who are having 10th and above years of schooling than the other counterparts in 2015-16 (Table 8). High-risk sexual behaviour has decreased among adolescent boys residing in urban areas (85 to $74 \%$ ) during the last decade, while it has increased among young men from $26 \%$ in $2005-$ 06 to $38 \%$ in $2015-16$. The results of the binary logistic regression analysis revealed that adolescent boys and young men residing in the urban setting are significantly two times $(p<0.01)$ and three times $(p<0.01)$, more prone to engage in high-risk sexual behaviour in the past 12 months during 2015-16.

Analysis shows that as wealth index increases, high-risk sexual behaviour increased among adolescent boys and young men in both the surveys, although the magnitude of change has also been reported. The richest quintile of adolescent boys shows the declining trend from $90 \%$ in $2005-06$ to $75 \%$ in $2015-16$. The results depicted that adolescent boys and young men having comprehensive knowledge of HIV/AIDS are more involved in high-risk sexual behaviour in both the surveys. Multivariate analysis shows that alcohol-using adolescent boys $(\mathrm{AOR}=1.82$; $p<0.01)$ and young men $(\mathrm{AOR}=2.38 ; p<0.01)$ were significantly more likely to engage in high-risk sexual behaviour in 2015-16 than their counterparts.

It was observed that high-risk sexual behaviour among adolescent boys and young men belonging to Northern, Central, and Eastern region has substantially increased from 2005-06 to 2015-16, which was lower in 2005-06 than the other geographical regions of India. The results of the multivariate analysis also revealed that adolescent boys and young men belonging to the Central region are three times $(p<0.01)$ and two times $(p<0.01)$ more likely to engage in high-risk sexual behaviour in the past 12 months in 2015-16 (Table 8).

\section{Discussion}

The present study attempted to assess the changes in sexual behaviour of adolescent boys and young men in India and associated factors using two rounds of NFHS survey. Adolescent sexuality has changed over the last five decades, with adolescents now reaching physical maturity earlier and marrying later. There are several factors which contribute to adolescents' reproductive health and behaviours. The socio-demographic elements which includes place of residence, family wealth, and own family composition provide the context for adolescent alternatives and decisions; individual characteristics which include academic and modern-day educational and employment repute make a contribution to the human assets that define adolescents' existent and shape their future [21-24].

The initiation of sexual activity is essential in the transition from adolescence to adulthood [25]. The finding of the study revealed that initiation of sexual activity is still early among adolescent boys (16 years) and young men (19 years) over the last decade in India. This finding indicates that premarital sexual behaviour is common among men and seems to be growing liberalism about sexuality among the youth [6]. This is similar to the findings from others studies conducted in various parts of India [26, 27].

The findings of the study revealed that condom use at sexual debut enhanced the probability of condom use during last sex, and this impact was to a great extent autonomous of the stimulus of stable demographic and individual attributes and proximate attitudinal, social, and relationship factors. This finding is predictable with the possibility that early condom use could help set up an example of condom utilize that conveys forward to resulting sexual activity $[28,29]$.

Having multiple sexual partners is significantly associated with the risk of sexually transmitted infections (STIs) among adolescents [30]. Findings indicated that adolescent boys were having a higher number of partners than the young men in both the survey rounds, however, multi-partner sexual behaviour among adolescent boys decreased over the last decade. Several studies have also documented that adolescents are more likely to report having multiple sexual partners than adults [30-32]. The major predictor of multiple sexual partners that emerged from the study was consuming alcohol. Alcohol using adolescent boys and young men were significantly more likely to have multiple sexual partners in both the surveys. It may be since adolescent boys and 
Table 3 Percentage distribution of adolescent boys and young men having multiple sexual partners in the last 12 months and results of zero inflated poison regression in India

\begin{tabular}{|c|c|c|c|c|c|c|c|c|}
\hline \multirow[b]{3}{*}{$\begin{array}{l}\text { Background } \\
\text { Characteristics }\end{array}$} & \multicolumn{4}{|c|}{ NFHS-3 (2005-06) } & \multicolumn{4}{|c|}{ NFHS-4 (2015-16) } \\
\hline & \multicolumn{2}{|l|}{$15-19$} & \multicolumn{2}{|l|}{$20-24$} & \multicolumn{2}{|l|}{$15-19$} & \multicolumn{2}{|l|}{$20-24$} \\
\hline & $\begin{array}{l}\text { Multiple } \\
\text { partners }\end{array}$ & $\operatorname{IRR}(\mathrm{Cl})$ & $\begin{array}{l}\text { Multiple } \\
\text { partners }\end{array}$ & $\operatorname{IRR}(\mathrm{Cl})$ & $\begin{array}{l}\text { Multiple } \\
\text { partners }\end{array}$ & $\operatorname{IRR}(\mathrm{Cl})$ & $\begin{array}{l}\text { Multiple } \\
\text { partners }\end{array}$ & $\operatorname{IRR}(\mathrm{Cl})$ \\
\hline \multicolumn{9}{|l|}{ Years of schooling } \\
\hline No education ${ }^{\oplus}$ & 8.4 & & 3.7 & & 2.4 & & 6.0 & \\
\hline$<5$ years & 14.1 & $1.37(0.90,2.08)$ & 7.7 & $1.03(0.88,1.20)$ & 15.3 & $0.74(0.43,1.28)$ & 5.1 & $1.14(0.95,1.36)$ \\
\hline $5-9$ & 15.8 & $1.10(0.78,1.55)$ & 5.3 & $0.82^{* * *}(0.72,0.92)$ & 11.8 & $0.87(0.63,1.20)$ & 5.3 & $1.04(0.91,1.18)$ \\
\hline 10 and above & 17.2 & $0.90(0.62,1.31)$ & 5.6 & $0.58^{* * *}(0.50,0.66)$ & 8.6 & $0.97(0.70,1.35)$ & 6.4 & $0.72^{* * *}(0.63,0.82)$ \\
\hline \multicolumn{9}{|l|}{ Residence } \\
\hline Rural $^{\oplus}$ & 13.0 & & 5.2 & & 11.1 & & 5.4 & \\
\hline Urban & 21.3 & $0.71^{* * *}(0.58,0.87)$ & 5.5 & $0.74^{* * *}(0.68,0.81)$ & 6.5 & $0.82^{* *}(0.69,0.97)$ & 6.9 & $0.86^{* * *}(0.79,0.92)$ \\
\hline \multicolumn{9}{|l|}{ Religion } \\
\hline $\mathrm{Hindu}^{\oplus}$ & 15.0 & & 5.0 & & 10.3 & & 5.7 & \\
\hline Muslim & 10.7 & $1.35^{* *}(1.04,1.75)$ & 6.4 & $1.10^{*}(0.98,1.24)$ & 7.7 & $1.13(0.89,1.42)$ & 5.0 & $0.95(0.86,1.05)$ \\
\hline Others & 22.0 & $0.83(0.61,1.12)$ & 8.4 & $1.03(0.90,1.16)$ & 6.9 & $1.66^{* * *}(1.31,2.11)$ & 10.5 & $1.04(0.93,1.16)$ \\
\hline \multicolumn{9}{|l|}{ Caste/tribe } \\
\hline Scheduled Caste ${ }^{\oplus}$ & 13.4 & & 5.8 & & 10.9 & & 6.1 & \\
\hline Scheduled Tribe & 9.1 & $0.92(0.68,1.24)$ & 3.3 & $1.03(0.90,1.18)$ & 6.5 & $0.94(0.76,1.16)$ & 5.0 & $1.002(0.91,1.10)$ \\
\hline $\begin{array}{l}\text { Other Backward } \\
\text { Class }\end{array}$ & 15.9 & $0.88(0.71,1.08)$ & 5.2 & $0.94(0.85,1.03)$ & 10.6 & $0.99(0.83,1.18)$ & 6.7 & $0.96(0.89,1.04)$ \\
\hline Others & 19.2 & $0.70^{* * *}(0.55,0.89)$ & 6.5 & $0.97(0.87,1.07)$ & 10.4 & $0.72^{* * *}(0.58,0.90)$ & 4.6 & $0.77^{* * * *}(0.69,0.85)$ \\
\hline \multicolumn{9}{|c|}{ Regular exposure of media } \\
\hline $\mathrm{No}^{\oplus}$ & 14.1 & & 3.6 & & 7.0 & & 5.2 & \\
\hline Yes & 14.9 & $0.90(0.69,1.17)$ & 5.8 & $0.92(0.82,1.03)$ & 10.4 & $1.19^{*}(0.97,1.46)$ & 6.0 & $0.90^{* *}(0.83,0.99)$ \\
\hline \multicolumn{9}{|l|}{ Wealth index } \\
\hline Poorest ${ }^{\oplus}$ & 12.1 & & 5.4 & & 9.4 & & 3.9 & \\
\hline Poorer & 13.0 & $0.99(0.75,1.31)$ & 5.6 & $1.09(0.94,1.25)$ & 10.0 & $0.81^{* *}(0.66,0.99)$ & 7.1 & $1.03(0.93,1.13)$ \\
\hline Middle & 10.1 & $0.69 * *(0.51,0.93)$ & 6.0 & $0.98(0.85,1.14)$ & 9.5 & $0.77^{* *}(0.62,0.97)$ & 6.4 & $1.04(0.93,1.15)$ \\
\hline Richer & 17.3 & $0.90(0.66,1.22)$ & 4.3 & $0.87^{*}(0.75,1.02)$ & 12.9 & $0.80^{*}(0.63,1.02)$ & 5.4 & $0.98(0.87,1.10)$ \\
\hline Richest & 29.1 & $0.80(0.57,1.12)$ & 5.0 & $0.74^{* * *}(0.63,0.88)$ & 7.0 & $0.75^{* *}(0.57,0.99)$ & 6.3 & $1.003(0.88,1.14)$ \\
\hline \multicolumn{9}{|c|}{ Comprehensive knowledge about HIV/AIDS } \\
\hline $\mathrm{No}^{\oplus}$ & 14.2 & & 5.0 & & 9.8 & & 5.4 & \\
\hline Yes & 16.7 & $1.67^{* * *}(1.24,2.25)$ & 6.4 & $0.97(0.90,1.05)$ & 8.2 & $0.92(0.70,1.20)$ & 8.2 & $1.06^{*}(0.99,1.12)$ \\
\hline \multicolumn{9}{|l|}{ Alcohol Use } \\
\hline $\mathrm{No} 0^{\oplus}$ & 10.3 & & 2.6 & & 8.4 & & 4.5 & \\
\hline Yes & 23.8 & $3.61 * * *(2.67,4.87)$ & 9.7 & $2.04^{* * *}(1.89,2.19)$ & 13.1 & $2.30^{* * *}(1.64,3.23)$ & 8.9 & $1.59 * * *(1.50,1.70)$ \\
\hline \multicolumn{9}{|l|}{ Region } \\
\hline North ${ }^{\oplus}$ & 17.6 & & 4.9 & & 6.9 & & 5.4 & \\
\hline Central & 12.5 & $1.02(0.80,1.30)$ & 7.4 & $1.07(0.96,1.20)$ & 11.7 & $1.77^{* * *}(1.47,2.13)$ & 7.3 & $1.17^{* * * *}(1.08,1.27)$ \\
\hline East & 16.2 & $0.52^{* * *}(0.37,0.73)$ & 4.9 & $0.54^{* * *}(0.45,0.63)$ & 10.5 & $0.87(0.68,1.10)$ & 2.5 & $0.79^{* * *}(0.71,0.88)$ \\
\hline Northeast & 10.9 & $0.45^{* * *}(0.32,0.62)$ & 4.0 & $0.58^{* * *}(0.50,0.66)$ & 6.5 & $0.52^{* * *}(0.39,0.70)$ & 3.0 & $0.65^{* * *}(0.57,0.74)$ \\
\hline West & 24.5 & $0.56^{* * *}(0.41,0.76)$ & 3.9 & $0.63^{* * *}(0.55,0.72)$ & 10.0 & $1.56^{* * *}(1.22,1.99)$ & 6.9 & $1.04(0.93,1.16)$ \\
\hline South & 2.7 & $0.15^{* * *}(0.11,0.22)$ & 3.4 & $0.43^{* * *}(0.38,0.48)$ & 1.7 & $0.17^{* * *}(0.11,0.27)$ & 7.0 & $0.42^{* * *}(0.36,0.48)$ \\
\hline Total & 14.8 & & 5.3 & & 9.8 & & 5.9 & \\
\hline
\end{tabular}

ब Reference, ${ }^{*} p<0.10 ;{ }^{* *} p<0.05 ;{ }^{* * *} p<0.01 ;$ IRR Incidence rate ratio; $\mathrm{Cl}$ Confidence interval 
Table 4 Relationships Status with the most recent partners among adolescent boys and young men in India

\begin{tabular}{|c|c|c|c|c|c|c|c|c|}
\hline & & & Spouse & Girlfriend/fiancé & Casual acquaintance & Commercial sex workers & Live-in partner & Others \\
\hline \multirow[t]{6}{*}{ NFHS-4 (2015-16) } & $15-19$ & Rural & 28.7 & 48.6 & 10.6 & 5.5 & 6.0 & 0.6 \\
\hline & & Urban & 16.2 & 57.2 & 6.5 & 8.4 & 10.9 & 0.8 \\
\hline & & Total & 25.2 & 51.0 & 9.5 & 6.3 & 7.4 & 0.7 \\
\hline & $20-24$ & Rural & 77.9 & 15.2 & 2.4 & 1.8 & 2.4 & 0.3 \\
\hline & & Urban & 60.2 & 28.2 & 4.9 & 2.2 & 4.1 & 0.4 \\
\hline & & Total & 72.5 & 19.2 & 3.2 & 1.9 & 2.9 & 0.3 \\
\hline \multirow[t]{6}{*}{ NFHS-3 (2005-06) } & $15-19$ & Rural & 44.6 & 29.6 & 2.3 & 2.3 & 0.6 & 20.6 \\
\hline & & Urban & 15.0 & 54.9 & 3.1 & 8.9 & 3.1 & 15.1 \\
\hline & & Total & 38.2 & 35.0 & 2.5 & 3.7 & 1.2 & 19.4 \\
\hline & $20-24$ & Rural & 87.3 & 5.7 & 0.8 & 0.9 & 0.5 & 4.9 \\
\hline & & Urban & 75.3 & 12.7 & 0.5 & 3.3 & 0.9 & 7.4 \\
\hline & & Total & 84.2 & 7.5 & 0.7 & 1.5 & 0.6 & 5.5 \\
\hline
\end{tabular}

young men get easily influenced by mass media, friends and peer pressure, leading them to experiment in risky lifestyles such as smoking, alcohol intake, drug consumption and sexual activity [13].

In modern India, the live-in relationship is becoming more common among youngsters. With urban India becoming more open-minded and the obvious western influence and students moving out of their homes at an early age, live-in relationships have become even more prevalent [33, 34]. Findings of the study also depicted that the percentage of adolescents having girlfriend, commercial sex workers, and live-in relationship has significantly increased in urban areas from NFHS-3 to NFHS-4. Results revealed that adolescent boys and young men residing in rural areas have also adopted the same culture during the last 10 years. Exposure of massmedia has played a major role in this transformation, giving the youth a level playing field through the Internet as a form of interaction with their metropolitan contemporaries. A noticeable outcome of this is the significant increase in the number of live-in relationships in small cities of India [35].

The risky sexual behaviour places individuals at high risk of sexually transmitted infections (STIs), like HIV/ AIDS, and having sex before being mature sufficient to distinguish what makes a healthy relationship. The findings highlighted that adolescent boys who had had at least 10th and above years of education, residing in urban areas, and belonging to the affluent class of households were more likely to engage in high-risk sexual activity than the young men in India. Moreover, the prevalence of high-risk sexual behaviour has significantly increased among both adolescent boys and young men from NFHS-3 (2005-06) to NFHS-4 (2015-16).

Alcohol and sexual activity have a very close and robust relation [36]. Alcohol consumption has regularly been referred as increasing adolescents' risk of HIV infection [37]. Consistent with the other studies, which are robust in other countries concerning risky sexual behaviour and alcohol consumption [38, 39]. Findings of present study

Table 5 Relationship with most recent partner according to socioeconomic status among adolescent boys (15-19) in India

\begin{tabular}{|c|c|c|c|c|c|c|c|}
\hline \multicolumn{2}{|l|}{ Socioeconomic Status } & \multirow{2}{*}{$\frac{\text { Spouse }}{32.4}$} & \multirow{2}{*}{$\frac{\text { Girlfriend/fiancé }}{41.2}$} & \multirow{2}{*}{$\frac{\text { Casual acquaintance }}{11.1}$} & \multirow{2}{*}{$\begin{array}{l}\text { Commercial sex worker } \\
7.8\end{array}$} & \multirow{2}{*}{$\begin{array}{l}\text { Live-in partner } \\
6.3\end{array}$} & \multirow{2}{*}{$\begin{array}{l}\text { Others } \\
1.2\end{array}$} \\
\hline NFHS-4 (2015-16) & Poorest & & & & & & \\
\hline & Poorer & 28.8 & 44.7 & 12.8 & 8.0 & 5.7 & 0.0 \\
\hline & Middle & 27.9 & 54.9 & 5.1 & 5.4 & 6.1 & 0.7 \\
\hline & Richer & 18.4 & 61.3 & 7.9 & 3.8 & 7.1 & 1.5 \\
\hline & Richest & 13.2 & 59.9 & 8.6 & 5.3 & 13.1 & 0.0 \\
\hline & Total & 25.2 & 51.0 & 9.5 & 6.3 & 7.4 & 0.7 \\
\hline \multirow[t]{6}{*}{ NFHS-3 (2005-06) } & Poorest & 45.0 & 32.2 & 1.6 & 1.9 & 0.0 & 19.3 \\
\hline & Poorer & 50.0 & 24.0 & 1.7 & 1.8 & 1.8 & 20.8 \\
\hline & Middle & 41.1 & 29.5 & 4.5 & 2.5 & 0.6 & 21.9 \\
\hline & Richer & 24.4 & 46.4 & 1.6 & 9.4 & 2.3 & 15.9 \\
\hline & Richest & 10.3 & 60.8 & 4.0 & 6.6 & 1.4 & 16.9 \\
\hline & Total & 38.2 & 35.0 & 2.5 & 3.7 & 1.2 & 19.4 \\
\hline
\end{tabular}


Table 6 Condom use at last sex with most recent partners among adolescent boys and young men in India

\begin{tabular}{|c|c|c|c|c|}
\hline \multirow{2}{*}{$\begin{array}{l}\text { Background } \\
\text { Characteristics }\end{array}$} & \multicolumn{2}{|c|}{ NFHS-3 (2005-06) } & \multicolumn{2}{|c|}{ NFHS-4 (2015-16) } \\
\hline & $15-19$ & $20-24$ & $15-19$ & $20-24$ \\
\hline
\end{tabular}

Years of schooling

$\begin{array}{lllll}\text { No education } & 12.0 & 5.8 & 46.8 & 68.3 \\ <5 \text { years } & 8.4 & 7.7 & 51.9 & 49.4 \\ 5-9 & 24.1 & 11.3 & 67.7 & 59.2 \\ 10 \text { and above } & 33.4 & 23.8 & 72.0 & 68.0\end{array}$

Residence

$\begin{array}{ccccc}\text { Rural } & 16.2 & 9.7 & 68.3 & 64.6 \\ \text { Urban } & 46.3 & 21.7 & 69.1 & 65.7 \\ \begin{array}{c}\text { Religion } \\ \text { Hindu }\end{array} & & & & \\ \text { Muslim } & 21.1 & 12.0 & 67.1 & 64.4 \\ \text { Others } & 27.0 & 12.9 & 71.9 & 66.0 \\ \text { Cas. } & 38.0 & 26.2 & 79.3 & 72.5\end{array}$

\section{Caste/tribe}

$\begin{array}{lllll}\text { Scheduled caste } & 18.8 & 12.4 & 77.1 & 72.1 \\ \text { Scheduled tribe } & 17.4 & 4.6 & 48.8 & 67.6 \\ \text { Other backward class } & 18.9 & 10.5 & 68.8 & 65.3 \\ \text { Others } & 39.3 & 21.0 & 63.7 & 61.1\end{array}$

Regular exposure of media

$\begin{array}{lllll}\text { No } & 11.5 & 5.1 & 62.5 & 38.1 \\ \text { Yes } & 25.2 & 14.8 & 69.2 & 67.7\end{array}$

Wealth index

$\begin{array}{lllll}\text { Poorest } & 11.5 & 3.7 & 62.8 & 62.5 \\ \text { Poorer } & 13.9 & 8.3 & 69.7 & 65.8 \\ \text { Middle } & 18.6 & 10.7 & 57.7 & 60.5 \\ \text { Richer } & 38.9 & 17.4 & 81.6 & 62.1 \\ \text { Richest } & 50.7 & 34.6 & 68.7 & 71.3\end{array}$

\section{Comprehensive knowledge about HIV/AIDS}

$\begin{array}{lllll}\text { No } & 21.8 & 11.5 & 66.4 & 64.3 \\ \text { Yes } & 36.5 & 19.6 & 72.2 & 67.1\end{array}$

\section{Alcohol Use}

\begin{tabular}{lllll} 
No & 19.7 & 11.8 & 68.7 & 61.0 \\
Yes & 28.7 & 14.3 & 68.6 & 72.0 \\
Region & & & & \\
North & 28.9 & 19.8 & 68.9 & 65.8 \\
Central & 19.9 & 12.4 & 66.3 & 57.6 \\
East & 14.2 & 6.9 & 66.3 & 64.7 \\
Northeast & 29.3 & 10.5 & 48.2 & 55.1 \\
West & 43.0 & 18.5 & 68.8 & 70.7 \\
South & 16.2 & 7.9 & 90.0 & 76.4 \\
Total & 22.7 & 12.8 & 68.8 & 65.1 \\
\hline
\end{tabular}

Table 7 High-risk sexual behaviour in the past 12 months among adolescent boys and young men in India

\begin{tabular}{|c|c|c|c|c|}
\hline \multirow{2}{*}{$\begin{array}{l}\text { Background } \\
\text { Characteristics }\end{array}$} & \multicolumn{2}{|c|}{ NFHS-3 (2005-06) } & \multicolumn{2}{|c|}{ NFHS-4 (2015-16) } \\
\hline & $15-19$ & $20-24$ & $15-19$ & $20-24$ \\
\hline \multicolumn{5}{|l|}{ Years of schooling } \\
\hline No education & 43.3 & 11.6 & 59.1 & 16.1 \\
\hline$<5$ years & 62.5 & 13.3 & 58.4 & 14.5 \\
\hline $5-9$ & 65.3 & 17.0 & 67.1 & 20.7 \\
\hline 10 and above & 75.4 & 27.8 & 74.2 & 36.8 \\
\hline \multicolumn{5}{|l|}{ Residence } \\
\hline Rural & 58.0 & 15.4 & 67.5 & 22.0 \\
\hline Urban & 85.1 & 25.8 & 74.4 & 38.0 \\
\hline \multicolumn{5}{|l|}{ Religion } \\
\hline Hindu & 65.8 & 16.8 & 69.5 & 26.8 \\
\hline Muslim & 46.6 & 20.3 & 68.2 & 21.0 \\
\hline Others & 73.9 & 35.6 & 73.4 & 42.5 \\
\hline \multicolumn{5}{|l|}{ Caste/tribe } \\
\hline Scheduled caste & 69.6 & 18.0 & 76.0 & 76.0 \\
\hline Scheduled tribe & 56.0 & 14.8 & 60.7 & 60.7 \\
\hline Other backward class & 59.3 & 15.3 & 67.1 & 67.1 \\
\hline Others & 75.1 & 25.0 & 79.8 & 79.8 \\
\hline
\end{tabular}

Regular exposure of media

$\begin{array}{lllll}\text { No } & 41.4 & 9.7 & 49.0 & 14.1 \\ \text { Yes } & 69.0 & 20.3 & 74.2 & 30.0\end{array}$

\section{Wealth index}

$\begin{array}{lllll}\text { Poorest } & 57.4 & 13.6 & 63.3 & 15.8 \\ \text { Poorer } & 52.9 & 14.0 & 67.4 & 22.3 \\ \text { Middle } & 60.8 & 17.9 & 67.7 & 23.1 \\ \text { Richer } & 77.3 & 19.9 & 77.6 & 34.6 \\ \text { Richest } & 89.7 & 32.1 & 74.9 & 43.9\end{array}$

\section{Comprehensive knowledge about HIV/AIDS}

$\begin{array}{lllll}\text { No } & 62.3 & 18.0 & 71.8 & 25.4 \\ \text { Yes } & 75.3 & 23.5 & 71.2 & 35.1\end{array}$

\section{Alcohol Use}

$\begin{array}{lllll}\text { No } & 60.6 & 13.3 & 67.1 & 23.5 \\ \text { Yes } & 70.4 & 25.7 & 75.0 & 34.3\end{array}$

\section{Region}

\begin{tabular}{lllll} 
North & 59.7 & 19.5 & 70.6 & 30.3 \\
Central & 67.2 & 19.6 & 81.5 & 32.6 \\
East & 46.7 & 13.2 & 58.5 & 12.7 \\
Northeast & 74.4 & 19.4 & 37.4 & 14.9 \\
West & 80.8 & 20.3 & 58.4 & 33.3 \\
South & 76.5 & 17.8 & 63.0 & 19.5 \\
Total & 63.8 & 18.1 & 69.5 & 26.9 \\
\hline
\end{tabular}


Table 8 Factor Associated with high-risk sexual behaviour among adolescent boys and young men in India

\begin{tabular}{|c|c|c|c|c|}
\hline \multirow{3}{*}{$\begin{array}{l}\text { Background } \\
\text { Characteristics }\end{array}$} & \multicolumn{2}{|c|}{ NFHS-3 (2005-06) } & \multicolumn{2}{|l|}{ NFHS-4 (2015-16) } \\
\hline & \multicolumn{2}{|c|}{ Adjusted Odds Ratio (Cl) } & \multicolumn{2}{|c|}{ Adjusted Odds Ratio (Cl) } \\
\hline & $15-19$ & $20-24$ & $15-19$ & $20-24$ \\
\hline \multicolumn{5}{|l|}{ Years of schooling } \\
\hline \multicolumn{5}{|l|}{ No education ${ }^{\circledast}$} \\
\hline$<5$ years & $1.63(0.64,4.13)$ & $1.08(0.68,1.7)$ & $4.57^{*}(0.81,25.6)$ & $0.95(0.58,1.56)$ \\
\hline $5-9$ & $1.57(0.75,3.31)$ & $1.38^{*}(0.98,1.96)$ & $1.20(0.55,2.6)$ & $1.24(0.88,1.76)$ \\
\hline 10 and above & $1.81(0.79,4.15)$ & $2.22^{* * *}(1.52,3.23)$ & $1.98^{*}(0.88,4.46)$ & $2.74^{* * *}(1.93,3.9)$ \\
\hline \multicolumn{5}{|l|}{ Residence } \\
\hline \multicolumn{5}{|l|}{ Rural $^{\circledast}$} \\
\hline Urban & $1.79 * *(1.06,3)$ & $1.30 * *(1.05,1.61)$ & $2.23^{* * *}(1.33,3.75)$ & $1.74^{* * *}(1.47,2.06)$ \\
\hline \multicolumn{5}{|l|}{ Religion } \\
\hline \multicolumn{5}{|l|}{$\mathrm{Hindu}^{\oplus}$} \\
\hline Muslim & $0.57^{*}(0.3,1.07)$ & $1.53^{* * *(1.14,2.05)}$ & $1.04(0.54,2.01)$ & $1.12(0.88,1.43)$ \\
\hline Others & $1.67(0.71,3.92)$ & $1.90 * * *(1.39,2.6)$ & $2.05^{*}(0.96,4.38)$ & $2.10^{* * *}(1.61,2.74)$ \\
\hline
\end{tabular}

\section{Caste/tribe}

\section{Scheduled caste ${ }^{\circledast}$ \\ Scheduled tribe \\ Other backward class \\ Others \\ Regular exposure of media \\ $\mathrm{No}^{\circledast}$}

Yes

$1.26(0.71,2.23)$
$0.96(0.67,1.36)$

$0.76^{* *}(0.58,0.98)$

$0.99(0.76,1.29)$

$1.55^{* *}(1.1,2.19)$

$0.73(0.49,1.09)$

0.93(0.63,1.36)

$0.86(0.58,1.29)$

$1.34(0.87,2.06)$
Richest

$\begin{array}{ll}\text { Poorest }^{\oplus} & \\ \text { Poorer } & 1.41(0.78,2.54) \\ \text { Middle } & 1.07(0.57,2.01) \\ \text { Richer } & 2.29^{* *}(1.12,4.7) \\ \text { Richest } & 2.82^{* *}(1.18,6.75)\end{array}$

\section{Comprehensive knowledge about HIV/AIDS}

$\mathrm{No}^{\oplus}$

Yes

\section{Alcohol Use}

$\mathrm{No}^{\circledR}$

Yes

Region

North $^{\oplus}$
Central
East
Northeast
West
South

Constant

$\begin{array}{ll}1.90^{* *}(1.05,3.42) & 1.14(0.84,1.53) \\ 1.25(0.56,2.82) & 0.64^{*}(0.39,1.03) \\ 1.39(0.62,3.16) & 1.27(0.89,1.83) \\ 2.91^{* *}(1.21,6.98) & 1.25(0.9,1.74) \\ 3.57^{* *}(1.32,9.64) & 0.87(0.62,1.23) \\ 0.777 & 0.088\end{array}$

$1.61 * * *(1.33,1.94)$

$0.51^{* * *}(0.39,0.67)$

$0.86(0.62,1.17)$

$1.31 * *(1.02,1.69)$

$0.60 * * *(0.42,0.85)$

0.065
$1.16(0.91,1.47)$

$1.03(0.85,1.24)$

$1.19(0.94,1.51)$

$1.22(0.96,1.57)$

$1.14(0.88,1.47)$

$1.32 *(1,1.74)$

$1.25^{* * *}(0.93,1.69)$

$1.30^{* * *}(1.13,1.5)$

'Reference, ${ }^{*} p<0.10$; ${ }^{* *} p<0.05 ;{ }^{* * *} p<0.01 ; \mathrm{Cl}$ Confidence intervals 
also confirmed a strong and significant relationship that alcohol using adolescent and young men is more likely to engage in high-risk sexual activity in both the consecutive surveys.

These findings revealed that there is an urgent need to concentrate awareness and educational efforts on the early adolescent in India. Early commencement into sexual behaviour among adolescent boys and young men anticipated a more significant level of sexual activity [40]. Additionally, it was also found that early initiation into sex at a younger age was fundamentally connected with having more lifetime sexual partners and the decision of first sexual partner. The existing key interventions to sexual and reproductive health (SRH) of adolescents in India focused on the prevention of disease transmission and handlings high-risk behaviours such as delaying sex debut, reducing the sexual relationship with multiple partners, and condom use [41]. Furthermore, the research on the sexual and reproductive health of adolescent boys has been ignored because these research or programs mainly concentrated on girls. As it is evident, sexual and reproductive health is interdependent among both genders, therefore, to ensure equitable gender roles, attitudes, behaviour, and outcomes we need more research and programs to emphasize young boys and men [2].

According to a 2014 report of Ministry of Health and Family Welfare India, about $21 \%$ of India's population are adolescents (10-19 years) [42, 43]. Lack of complete and thorough sex-education, inaccessibility and lack of awareness about contraceptives, incorrect sex-education because of early presentation to pornography, etc., ending in unhealthy sexual practices and reproductive illhealth are enormous issues that plague the young. They moreover meddled with an important advancement of a person and community. Keeping in mind the changing pattern of the society in India, the Government of India has drawn out the National Education Policy, 2016, which acknowledges the importance of sex-education in schools for adolescent for wellbeing measures [44]. It is not yet clear if this approach will be actualized this time over. The time has come for the educators to understand that impractical, improper knowledge about sex can be perilous and it is better for the adolescent to be aware and organised.

However, the reality is that sexuality education for adolescents is an exceptionally dubious subjects in India. It is viewed as hostile to Indian qualities, and worries that it may prompt hazardous sexual conduct and wantonness [45]. Consequently, youngsters in India don't approach thorough sexuality training. Indeed, even among couples, conversations around sex and sexuality seldom occur, as it is taboo [46]. There are no particular instructive educational plans for giving sexuality instruction to class school going youngsters, and it's excluded inside the advising preparing educational plan. Laws ensuring conceptive rights are not adjusted and there is no particular law on sexual rights in India.

\section{Conclusions}

The study concludes that early sexual debut, lower prevalence of condom use at first sexual experience, and alcohol consumption indicate the dangerous interconnection between such behaviours among adolescent boys over the last decade. Therefore, there is an urgent need to adopt integrated approach of prevention strategies at various levels to generate awareness regarding the potential health hazards of alcohol and premarital sexual relationships that could target multiple forms of risky behaviours of adolescent boys. The concept of live-in relationship has also emerged among rural adolescent boys and young men, and not only among urban youth during the last 10 years. The government of India should fix a legal age to be in a live-in relationship among young population. Emerging evidence shows that Indian demographic health survey should also conduct a special survey on adolescent sexual and reproductive health, which will help in a better understanding of the nature of problems among adolescents in India, leading to their causes and solution.

\section{Abbreviations \\ NFHS: National family health Survey; DHS: Demographic Health Survey; AOR: Adjusted Odds Ratio; WHO: World Health Organization; JJ Act: Juvenile Justice Act; POCSO Act: Protection of Children from Sexual Offences Act; GOI: Government of India; HIV: Human Immunodeficiency Virus; AIDS: Acquired Immunodeficiency Syndrome; STDs: Sexually Transmitted Diseases; IIPS: International Institute for Population Sciences; IRR: Incidence rate Ratio}

\section{Acknowledgements}

The authors of the paper acknowledge the DHS USAID for freely providing data to conduct this research.

\section{Authors' contributions}

SKS developed the concept, analyse the data and written the manuscript and DV has written and edited the manuscript thoroughly. Both Authors read and approved the final manuscript.

\section{Funding}

There is no funding for this research. This is an independent research.

\section{Availability of data and materials}

It is worth mentioning that the dataset is available in the public domain subject to a prescribed registration and approval process. Requisite permission in accessing and usage of dataset was obtained from the MEASURE-DHS archive.

Ethics approval and consent to participate

Requisite permission in accessing and usage of dataset was obtained from the MEASURE-DHS archive.

Consent for publication

Not Applicable

Competing interests

The authors declare that they have no competing interests. 


\section{Author details}

International Institute for Population Sciences, Deonar, Govandi Station Road, Mumbai, Maharashtra 400088, India. ${ }^{2}$ Deepanjali Vishwakarma, Doctoral Fellow, International Institute for Population Sciences, Deonar, Mumbai, India.

Received: 21 September 2019 Accepted: 1 July 2020

Published online: 11 July 2020

\section{References}

1. Shashikumar R, Das RC, Prabhu H, Srivastava K, Bhat PS, Prakash J, et al. A cross-sectional study of factors associated with adolescent sexual activity. Indian J Psychiatry. 2012;54(2):138-43. https://doi.org/10.4103/0019-5545. 99532.

2. Srivastava NM. Adolescent health in India: need for more interventional research. Clin Epidemio Glob Health. 2016;4(3):101-2.

3. Pringle J, Mills KL, McAteer J, Jepson R, Hogg E, Anand N, Blakemore SJ. The physiology of adolescent sexual behaviour: a systematic review. Cogent Soc Sci. 2017;3(1):1368858. https://doi.org/10.1080/23311886.2017.1368858.

4. WHO. Department of Reproductive Health and Research. Expanding access to contraceptive services for adolescents. 2012; 4 pp. https://www.gov.uk/ dfid-research-outputs/expanding-access-to-contraceptive-services-foradolescents

5. Maswikwa B, Richter L, Kaufman J, Nandi A. Minimum marriage age Laws and the prevalence of child marriage and adolescent birth: evidence from sub-Saharan Africa. Int Perspect Sex Reprod Health. 2015;41(2):58-68. https://doi.org/10.1363/4105815.

6. Joshi PD. Indian adolescent sexuality: sexual knowledge, attitudes, and Behaviours among urban youth. Psycho Stud. 2010;55(3):181-7. https://doi. org/10.1007/s12646-010-0018-1.

7. Government of India, Ministry of Women and Child Development. Deliberations on JJ Act 2015 and POSCO Act 2012. National Consultation on Child Protection, 2018. https://wcd.nic.in/sites/default/files/pocsoact\%2 0by\%20AS\%20-05.06.2018.pdf.

8. Tulloch T, Kaufman M. Adolescent sexuality. Pediatr Rev. 2013;34(1):29-38. https://doi.org/10.1542/pir.34-1-29.

9. Auslander BA, Rosenthal SL, Blythe MJ. Understanding sexual behaviors of adolescents within a biopsychosocial framework. Adolesc Med State Art Rev. 2007:18:434-48.

10. Ott MA. Examining the development and sexual behavior of adolescent males. J Adolesc Health. 2010;46(4 Suppl):S3-11. https://doi.org/10.1016/j. jadohealth.2010.01.017.

11. Kar SK, Choudhury A, Singh AP. Understanding normal development of adolescent sexuality: a bumpy ride. J Hum Reprod Sci. 2015;8(2):70-4. https://doi.org/10.4103/0974-1208.158594.

12. Joshi B, Chauhan S. Determinants of youth sexual behaviour: program implications for India. East J Medicine. 2011;16(2):113-21.

13. Sharma N. Love matters: romantic and sexual relationships among youth of slum of Mumbai metropolitan. Popul Association of America (PAA). 2012; https://epc2012.princeton.edu/papers/121203.

14. Chandran A. Siraj KA. A Study on the Alcoholic Addiction and Adaptation of Risky Sexual Behavioural Patterns among Youth. In: Anuradhalakshmi PR, Joseph JV, Reddy W. National Conference on Effect of Substance Abuse on Society. Shanlax Int J Arts, Science and Humanities. 2016; 4:1:139-147. http://www.shanlaxjournals.in/pdf/SPL/Kodaikanal-Socialwork-ASH.pdf.

15. Lugoe WL, Klepp KI, Skutle A. Sexual debut and predictors of condom use among secondary school students in Arusha. Tanzania AIDS Care. 1996;8(4): 443-52. https://doi.org/10.1080/09540129650125632.

16. Meekers D, Klein M. Determinants of condom use among young people in urban Cameroon. Stud Fam Plan. 2002;33(4):335-46. https://doi.org/10.1111/ j.1728-4465.2002.00335.x

17. Santhya KG, Acharya R, Jejeebhoy SJ. Condom use before marriage and its correlates: evidence from India. Int Perspect Sex Reprod Health. 2011;37(4): 170-80. https://doi.org/10.1363/3717011

18. Juarez F, LeGrand T. Factors influencing boys' age at first intercourse and condom use in the shantytowns of Recife. Brazil Stud Fam Plann. 2005;36(1): 57-70. https://doi.org/10.1111/j.1728-4465.2005.00041.x.

19. Prata N, Morris L, Mazive E, Vahidnia F, Stehr M. Relationship between HIV risk perception and condom use: evidence from a population-based survey in Mozambique. Int Fam Plan Perspect. 2006;32(4):192-200. https://doi.org/ $10.1363 / 3219206$.
20. International Institute for Population Sciences (IIPS) and ICF. National Family Health Survey (NFHS-4), 2015-16: India. Mumbai: IIPS.2017. http://rchiips.org/ nfhs/NFHS-4Reports/India.

21. Blanc AK, Tsui AO, Croft TN, Trevitt JL. Patterns and trends in adolescents' contraceptive use and discontinuation in developing countries and comparisons with adult women. Int Perspect Sex Reprod Health. 2009;35(2): 63-71.

22. Lloyd CB, Behrman JR, Stormquist NP, Cohen B. The Changing Transitions to Adulthood in Developing Countries. National Research Council, \& Committee on Population. Washington, D.C: National Academic Press; 2005.

23. Rani M, Lule E. Exploring the socioeconomic dimension of adolescent reproductive health: a multicountry analysis. Int Fam Plan Perspect. 2004; 30(3):110-7. https://doi.org/10.1363/3011004.

24. Guiella G, Madise NJ. HIV/AIDS and sexual-risk behaviors among adolescents: factors influencing the use of condoms in Burkina Faso. Afr J Reprod Health. 2007;11(3):182-96.

25. Upchurch DM, Levy-Storms L, Sucoff CA, Aneshensel CS. Gender and ethnic differences in the timing of first sexual intercourse. Fam Plan Perspect. 1998; 30(3):121-7.

26. Maheswari SU, Kalaivani S. Pattern of sexual behavior in adolescents and young adults attending STD clinic in a tertiary care center in South India. Indian J Sex Transm Dis AIDS. 2017;38(2):171-5. https://doi.org/10.4103/ijstd. IJSTD_9_16.

27. Taraphdar P, Dasgupta A, Saha B. Coital debut of people living with HIV/ AIDS attending school of tropical medicine. Kolkata Indian J Public Health. 2009:53(4):240-2.

28. Harrison A, Cleland J, Gouws E, Frohlich J. Early sexual debut among young men in rural South Africa: heightened vulnerability to sexual risk? Sex Transm Infect. 2005;81(3):259-61. https://doi.org/10.1136/sti.2004.011486.

29. Shafii T, Stovel K, Davis R, Holmes K. Is condom use habit forming? Condom use at sexual debut and subsequent condom use. Sex Transm Dis. 2004; 31(6):366-72. https://doi.org/10.1097/00007435-200406000-00010.

30. Vasilenko SA, Lanza ST. Predictors of multiple sexual partners from adolescence through young adulthood. J Adolesc Health. 2014;55(4):491-7. https://doi.org/10.1016/j.jadohealth.2013.12.025.

31. Forrest JD, Singh $\mathrm{S}$. The sexual and reproductive behaviour of American women, 1982-1988. Fam Plan Perspect. 1990;22(5):206-14.

32. Santelli JS, Brener ND, Lowny R, Bhatt A, Zabin LS. Multiple sexual partners among U.S. adolescents and young adults. Fam Plan Perspect. 1998;30(6):271-5.

33. Abhang S. Judicial approach to "live-in-relationship" in India-its impact on other related statutes. J Human Soci Sci. 2014;19.

34. Jawale Kalpana Vithalrao, Live-In Relationship: Recent Development and Challenges in India. 2012. https://ssrn.com/abstract=2046460 or https://doi. org/10.2139/ssrn.2046460.

35. Acharya K, Udgata S. Live-In-Relationships in India and Their Impact-A Sociological Study. 2019. Available at SSRN 3451288. https://papers.ssrn. com/sol3/papers.cfm?abstract_id=3451288.

36. Ramadugu S, Ryali V, Srivastava K, Bhat PS, Prakash J. Understanding sexuality among Indian urban school adolescents. Ind Psychiatry J. 2011; 20(1):49-55. https://doi.org/10.4103/0972-6748.98416.

37. Morrison DM, Gillmore MR, Hoppe MJ, Gaylord J, Leigh BC, Rainey D. Adolescent drinking and sex: findings from a daily diary study. Perspect Sex Reprod Health. 2003:35(4):162-8. https://doi.org/10.1363/psrh.35.162.03.

38. Demen KH, Cooper ML, Agocha VB. Sex-related alcohol expectancies as moderators of the relationship between alcohol use and risky sex in adolescents. J Stud Alcohol. 1998:59:71-7.

39. Olley BO. Child sexual abuse, harmful alcohol use and age as determinants of sexual risk behaviours among freshmen in Nigerian University. Afr J Reprod Health. 2008;12(2):75-88.

40. Brahme RG, Sahay S, Kohli RM, Divekar AD, Gangakhedkar RR, Parkhe AP, Kharat MP, Risbud AR, Bollinger RC, Mehendale SM, Paranjape RS. High-risk behaviour in young men attending sexually transmitted disease clinics in Pune, India. AIDS Care. 2005;17(3):377-85.

41. Vranda MN, Subbakrishna DK, Ramakrishna J, Veena HG. Sexual and reproductive health concerns of adolescent's living with perinatally infected HIV in India. Ind J Community Med. 2018:43(3):239-42. https://doi.org/10. 4103/ijcm.IJCM_5_18.

42. Sivagurunathan C, Umadevi R, Rama R, Gopalakrishnan S. Adolescent health: present status and its related programmes in India. Are we in the right direction? J Clin Diagn Res. 2015:9(3):LE01-LE6. https//doi.org/10.7860/ JCDR/2015/11199.5649. 
43. Strategy Handbook. Rashtriya Kishor Swasthya Karyakram. Adolescent Health Division Ministry of Health and Family Welfare Government of India. January 2014 [Internet]. Available from: https:/www.dropbox.com/s/0oj4p422y7st4 ku/\%20RKSK\%20Strategy\%20Handbook.pdf. [cited 8 Sept 2014].

44. Ministry of Human Resource Development. National Policy on Education 2016. Report of the Committee for Evolution of the New Education Policy Government of India 2016. http://img.asercentre.org/docs//mpact/ASER\%2 Oaserimpactreportnep.pdf.

45. Khubchandani J, Clark J, Kumar R. Beyond controversies: sexuality education for adolescents in India. J Family Med Prim Care. 2014;3(3):175-9. https:// doi.org/10.4103/2249-4863.141588.

46. Marlow HM, Tolley EE, Kohli R, Mehendale S. Sexual communication among married couples in the context of a microbicide clinical trial and acceptability study in Pune, India. Cult Health Sex. 2010;12(8):899-912. https://doi.org/10.1080/13691058.2010.508843

\section{Publisher's Note}

Springer Nature remains neutral with regard to jurisdictional claims in published maps and institutional affiliations.

Ready to submit your research? Choose BMC and benefit from:

- fast, convenient online submission

- thorough peer review by experienced researchers in your field

- rapid publication on acceptance

- support for research data, including large and complex data types

- gold Open Access which fosters wider collaboration and increased citations

- maximum visibility for your research: over $100 \mathrm{M}$ website views per year

At BMC, research is always in progress.

Learn more biomedcentral.com/submissions 